\title{
Double-blind cross-over comparison of aceclidine and pilocarpine in open-angle glaucoma
}

\author{
JOHN H. ROMANO \\ Glaucoma Clinic, Moorfields Eye Hospital, London
}

Aceclidine hydrochloride (3-acetoxyquinuclidine, "Glaucostat": Chibret) used topically in a strength of 2 per cent. is a parasympathomimetic drug acting directly on the motor end-plate (cholinergic nerve-endings). It is suitable for administration as eye drops, penetrating rapidly into the anterior chamber. It is a synthetic substance and was first prepared in Russia by Rubitzov and Miklina (1960). The name "Aceclidine" was coined by Mashkovski and Zaitzeva (1960), who studied its pharmacological aspects. It was also described by Sharts and Shulpina (196i).

Numerous clinical trials in Russia, France, and Italy and in other countries have led to its widespread use on the continent of Europe, including the U.S.S.R. In several centres it is used routinely as an alternative to pilocarpine or when pilocarpine fails.

The drug has also been investigated in the United States of America by Lieberman and Leopold (1967), who described a definite lowering of intraocular pressure with no corresponding increase in facility of outflow. Aceclidine is not in clinical use in the U.S.A.

Our interest was stimulated by these early reports. No fully satisfactory topical directacting parasympathomimetic drug is available as an alternative to pilocarpine if for any reason this is or becomes unsuitable. In such cases resort is usually made to cholinesteraseinhibiting substances-eserine, prostigmine (neostigmine), or one of the "irreversible" cholinesterase inhibitors, di-isopropylfluorophosphonate (DFP), phospholine iodide, demecarium bromide, etc.

The use of the latter group of drugs is not without its disadvantages or dangers. Of 9 the available direct parasympathetic stimulating drops, acetylcholine itself is too unstable $\rightarrow$ to remain in solution for more than a few minutes. Carcholin (carbachol, Doryl, carbamylcholine chloride, a synthetic drug) 0.75 to 3 per cent. has poor corneal penetra- N tion, being hydrophilic, and must be used with a wetting agent in methyl cellulose (Shaffer, N 1967), or as a dry suspension in anhydrous vehicles (Swan, 1959). Methacholine (Mecholyl) io to 20 per cent. is unstable and short-acting and must be used every 5 to 10 g minutes. Arecoline, the alkaloid of the betel nut, was tried in ophthalmology in r 895 but 0 never used in practice. Its formula is similar to that of aceclidine. Furmethide (furfuryl $\mathbb{D}$ methyl ammonium iodide) and urecholine (urethane of beta-methyl choline) have also been abandoned.

Among the obvious advantages that aceclidine appears to offer over the preceding drugs are its stability, penetration, and long shelf-life. 


\section{Pharmacology}

Aceclidine is 3-acetoxyquinuclidine (cf. molecular structure. Figure).<smiles>CC(=O)OC1CN2CCC1CC2</smiles>

FIGURE Structural formula of aceclidine hydrochloride

It is available as:

(i) The salicylate (molecular weight $308 \cdot 34$, a 2 per cent. concentration corresponding to an 0.065 molar solution). This is the preparation used by Lieberman and Leopold (1967). A 2 per cent. solution of aceclidine salicylate is only 0.79 times as concentrated a molar solution as 2 per cent. pilocarpine nitrate.

(ii) Aceclidine hydrochloride (Glaucostat) with a molecular weight of 205.5. A 2 per cent. solution of the hydrochloride corresponds to an 0.097 molar solution. It is interesting that pilocarpine $\mathrm{HCl}$ has a molecular weight of $244^{\circ} 7 \mathrm{I}$, a 2 per cent. solution corresponding to an 0.82 molar solution, i.e. intermediate between the two forms of aceclidine (Table I).

Table I Formula of 2 per cent. aceclidine hydrochloride eye drops

3-acetoxyquinuclidine hydrochloride $\ldots \ldots \ldots \ldots \ldots \ldots \ldots \ldots$ g.

Boric acid $\ldots \ldots \ldots \ldots \ldots \ldots \ldots \ldots \ldots \ldots \ldots \ldots \ldots \ldots \ldots \ldots$ r 8 g.

Sodium borate.......................

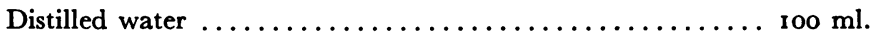

Aceclidine has a potent parasympathomimetic action in man and experimental animals and a very weak anticholinesterase activity. This action is accordingly abolished or greatly weakened by atropine but almost unaffected by cholinesterase (Mashkovski and Zaitzeva, 1960). In experimental animals it possesses a parasympathomimetic action superior to that of a similar dose of pilocarpine. It is less toxic than pilocarpine, the L.D.5o being $0.116 \mathrm{~g} . / \mathrm{kg}$. (in mouse intraperitoneally) and $0.105 \mathrm{~g} . / \mathrm{kg}$. (in rat)-approximately twice that of pilocarpine. No tachyphylaxis has been noted after repeated doses in contrast to that seen with pilocarpine (Yankelowitz, ig65).

It is prepared in a lyophilized form and is mixed at the time of dispensing. In powder form it undergoes only a 5 per cent. loss of activity after 3 months at $37^{\circ} \mathrm{C}$. and can be used for up to 3 years. In solution a similar loss of activity occurs after 30 days at $22^{\circ} \mathrm{C}$. (Tarrerias and Vassallo, I967). The $\mathrm{pH}$ of the hydrochloride before bottling is 6.6o. That of a 2 per cent. pilocarpine $\mathrm{HCl}$ solution is $4 \cdot 8$. On storing, aceclidine undergoes a slight fall in $\mathrm{pH}$ to $6 \cdot 43$, whereas pilocarpine tends to become more acidic.

No irritation in human subjects is recorded with a 2 to 4 per cent. solution, or in the rabbit eye with a 20 per cent. solution (Yankelowitz, 1965). The drug penetrates rapidly into the anterior chamber (Rouher, I966). 


\section{Description of the trial}

The object of the trial was a direct comparison of the effect on the same eyes and under identical conditions of gutt. pilocarpine 2 per cent. and gutt. aceclidine $\mathrm{HCl} 2$ per cent., both used three times a day. One eye received pilocarpine and the other aceclidine. The eyes were examined at the end of one week of therapy, and after a fixed interval, I $\frac{1}{2}$ hours, from the last instillation. The following conditions were thought to be desirable:

(a) Double-blind conditions to ensure lack of bias on the part of the patient in describing the symptoms, and greater objectivity on the part of the observer.

(b) Use of a placebo for one week to each eye to eliminate the effect of previous medication; it is claimed that $3^{2}$ hours are sufficient for this purpose (Agugini and Stecchi, I968).

(c) Cross-over after a further week of placebo.

\section{MATERIAL AND METHODS}

The trial covered a total of 54 eyes (27 cases). All were established cases of open-angle (chronic simple) glaucoma undergoing nedical treatment (with pilocarpine: 36 eyes; pilocarpine and eserine: 3 eyes; pilocarpine and neutral adrenaline: 16 eyes; phospholine iodide and neutral adrenaline: 1 eye; adrenaline alone: 2 eyes).

SUITABILITY OF GASES

(I) No patient undergoing therapy with a carbonic anhydrase inhibitor and only one eye previously on a powerful anticholinesterase drug was included in the test. (In two eyes neutral adrenaline was continued during the trial.)

(2) Visual acuity had to be at least $1 / 60$ in each eye to allow tonography to be performed in both eyes.

(3) Patients fulfilling the above requirements were considered suitable for the "full trial" (see later) only if their anterior chamber depth and configuration were such that angle closure was considered unlikely to occur when miotic therapy was interrupted for a week. Patients with a previouslyrecorded high level of intraocular pressure (greater than $28-30 \mathrm{~mm}$. $\mathrm{Hg}$ ) were also considered unsuitable for the full trial.

In Groups 2 and 3, the non-placebo or shorter trial was carried out.

\section{A. Full Trial (34 eyes) (Table IIA, opposite)}

(I) First visit: Nature of trial explained: whatever the frequency of previous medication, drops to be used three times a day during trial (7.0 a.m., 2.0 p.m., and I 0.0 p.m. whenever possible).

On day of attendance at clinic, however, mid-day instillation set at a specified hour $N$ (usually 1.30 or 2.0 p.m.) so that a constant interval should elapse before tonometry. N Patient requested to observe and note various symptoms (see later) following use of drops, with special attention to comparison of the two eyes.

Two bottles dispensed marked Right and Left containing placebo (physiological saline) to enable patients to practise adhering to new routine of treatment.

(2) Second visit (after 7 days).

(a) Questionnaire: contrasting and comparing effects on the two eyes as regards: pain/ 
Table IIA Clinical particulars of 17 full trial cases (34 eyes)

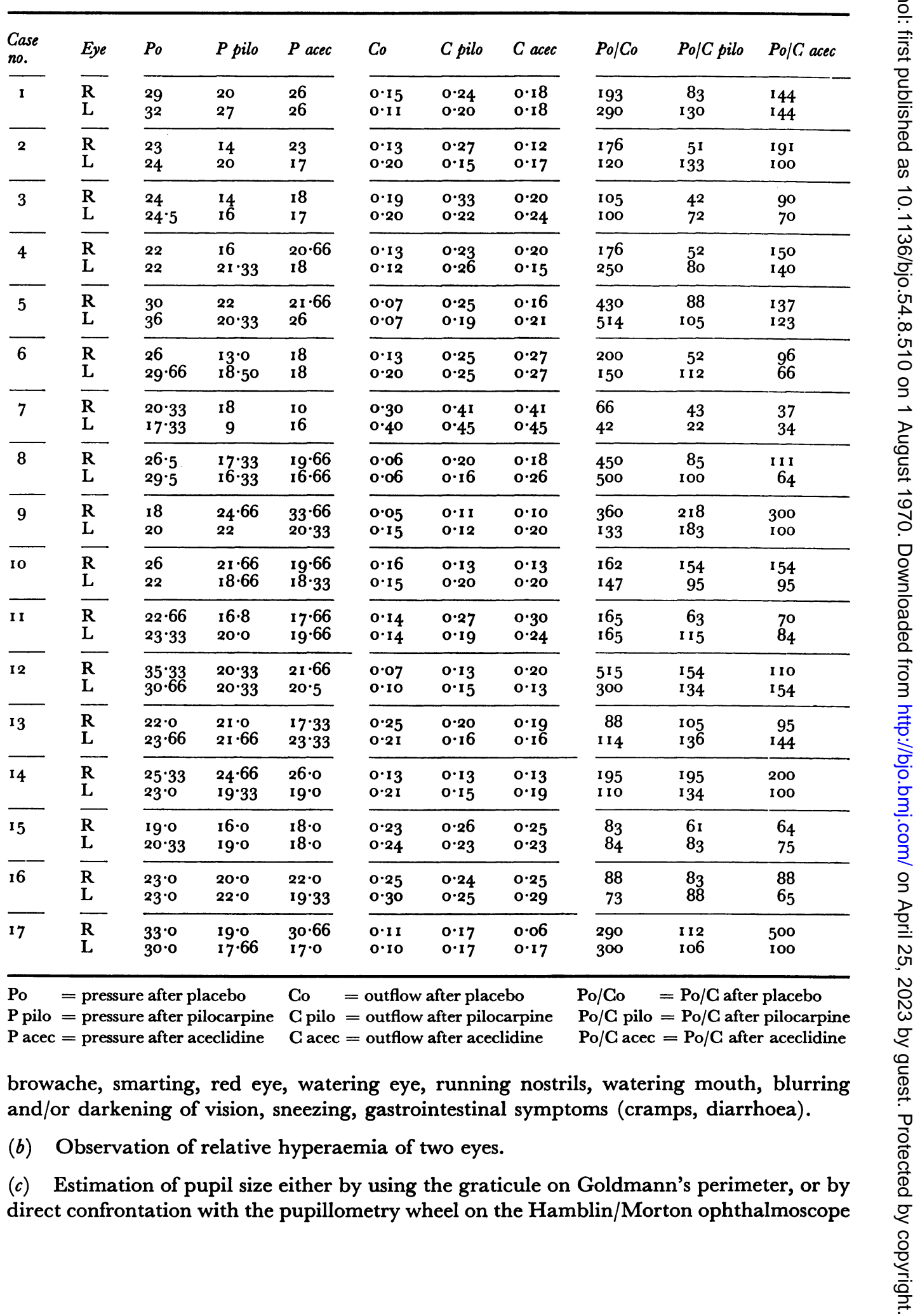


under uniform conditions of lighting and fixing distant object. With practice, accuracy of $0.25 \mathrm{~mm}$. is possible (e.g. between the 2.5 and $3.0 \mathrm{~mm}$. marks), considered adequate for the purposes of the test.

(d) Applanation tonometry: using Goldmann tonometer mounted on Haag-Streit 900 slit lamp, checked for accuracy before each session with calibration device for 20 and $60 \mathrm{~mm}$. Hg. Three readings made on each eye, changing eyes between each reading, and mean pressure recorded.

(e) Tonography: using Schwarzer recording tonometer. $\mathrm{P}_{\mathrm{o}}$ taken as applanation reading. As far as possible 45 to 60 minutes allowed to elapse between recording of two eyes. Only good tracings accepted. Correction for scleral rigidity not included.

( $f$ ) Pilocarpine 2 per cent. and aceclidine 2 per cent. dispensed at Hospital Pharmacy in bottles marked Right and Left plus a code symbol corresponding to a number in a scientifically randomized series.

(3) Third visit (end of second week). Questionnaire, etc., as on second visit.

Two sets of drops issued; (a) Two bottles of placebo for third week; (b) Two bottles of pilocarpine/aceclidine in sealed envelope for use at beginning of week four (date specified on envelope).

(4) Fourth visit (I 4 days after third visit). Procedure as at third visit.

At the conclusion of the trial each patient resumed his previous therapy.

B. Non-placebo or "Short" Trial (20 eyes) (Table IIB)

Table IIB Clinical particulars of 10 non-placebo cases (20 eyes)

\begin{tabular}{|c|c|c|c|c|c|c|c|}
\hline $\begin{array}{l}\text { Case } \\
\text { no. }\end{array}$ & Eye & $P$ acec & $P$ pilo & $C$ acec & $C$ pilo & $P_{\mathrm{o}} / C$ acec & $P_{\mathrm{o}} / C$ pilo \\
\hline I & $\begin{array}{l}\mathrm{R} \\
\mathrm{L}\end{array}$ & $\begin{array}{l}23 \\
24 \cdot 1\end{array}$ & $\begin{array}{l}22 \cdot 66 \\
25 \cdot 0\end{array}$ & $\begin{array}{l}0.13 \\
0.09\end{array}$ & $\begin{array}{l}0 \cdot 13 \\
0 \cdot 10\end{array}$ & $\begin{array}{l}175 \\
265\end{array}$ & $\begin{array}{l}175 \\
250\end{array}$ \\
\hline 2 & $\begin{array}{l}\mathrm{R} \\
\mathrm{L}\end{array}$ & $\begin{array}{l}20 \cdot 33 \\
16 \cdot 0\end{array}$ & $\begin{array}{l}19.88 \\
15.66\end{array}$ & $\begin{array}{l}0.13 \\
0.26\end{array}$ & $\begin{array}{l}0 \cdot 30 \\
0 \cdot 12\end{array}$ & $\begin{array}{r}154 \\
62\end{array}$ & $\begin{array}{r}67 \\
133\end{array}$ \\
\hline 3 & $\begin{array}{l}\mathbf{R} \\
\mathbf{L}\end{array}$ & $\begin{array}{l}24^{\circ} 0 \\
24^{\circ} 0\end{array}$ & $\begin{array}{l}24 \cdot 33 \\
23 \cdot 16\end{array}$ & $\begin{array}{l}0.26 \\
0.13\end{array}$ & $\begin{array}{l}0 \cdot 16 \\
0 \cdot 21\end{array}$ & $\begin{array}{r}92 \\
185\end{array}$ & $\begin{array}{l}150 \\
110\end{array}$ \\
\hline 4 & $\begin{array}{l}\mathrm{R} \\
\mathrm{L}\end{array}$ & $\begin{array}{l}21 \cdot 66 \\
18 \cdot 0\end{array}$ & $\begin{array}{l}14 \cdot 0 \\
13 \cdot 0\end{array}$ & $\begin{array}{l}0 \cdot 12 \\
0 \cdot 08\end{array}$ & $\begin{array}{l}0 \cdot 11 \\
0 \cdot 11\end{array}$ & $\begin{array}{l}183 \\
222\end{array}$ & $\begin{array}{l}128 \\
118\end{array}$ \\
\hline 5 & $\begin{array}{l}\mathrm{R} \\
\mathrm{L}\end{array}$ & $\begin{array}{l}30 \cdot 66 \\
28 \cdot 0\end{array}$ & $\begin{array}{l}28 \cdot 0 \\
27 \cdot 33 \\
\end{array}$ & $\begin{array}{l}0 \cdot 10 \\
0 \cdot 10\end{array}$ & $\begin{array}{l}0.14 \\
0.18\end{array}$ & $\begin{array}{l}310 \\
280\end{array}$ & $\begin{array}{l}200 \\
150\end{array}$ \\
\hline 6 & $\begin{array}{l}\mathbf{R} \\
\mathbf{L}\end{array}$ & $\begin{array}{l}37^{\circ} 0 \\
3^{2} \cdot 0\end{array}$ & $\begin{array}{l}30 \cdot 0 \\
26 \cdot 66\end{array}$ & $\begin{array}{l}0.18 \\
0.11\end{array}$ & $\begin{array}{l}0.15 \\
0.14\end{array}$ & $\begin{array}{l}205 \\
280\end{array}$ & $\begin{array}{l}200 \\
194\end{array}$ \\
\hline 7 & $\begin{array}{l}\mathbf{R} \\
\mathbf{L}\end{array}$ & $\begin{array}{l}18 \cdot 66 \\
21 \cdot 33\end{array}$ & $\begin{array}{l}19.33 \\
17.66\end{array}$ & $\begin{array}{l}0.17 \\
0.19\end{array}$ & $\begin{array}{l}0.24 \\
0.17\end{array}$ & $\begin{array}{l}112 \\
113\end{array}$ & $\begin{array}{r}83 \\
106\end{array}$ \\
\hline 8 & $\begin{array}{l}\mathbf{R} \\
\mathbf{L}\end{array}$ & $\begin{array}{l}23 \cdot 33 \\
20 \cdot 0\end{array}$ & $\begin{array}{l}21 \cdot 66 \\
20 \cdot 0\end{array}$ & $\begin{array}{l}0 \cdot 31 \\
0 \cdot 19\end{array}$ & $\begin{array}{l}0.20 \\
0.24\end{array}$ & $\begin{array}{r}77 \\
105\end{array}$ & $\begin{array}{r}110 \\
83\end{array}$ \\
\hline 9 & $\begin{array}{l}\mathbf{R} \\
\mathbf{L} \\
\end{array}$ & $\begin{array}{l}27 \cdot 33 \\
24 \cdot 0 \\
\end{array}$ & $\begin{array}{l}37 \cdot 33 \\
16 \cdot 66\end{array}$ & $\begin{array}{l}0.10 \\
0.09\end{array}$ & $\begin{array}{l}0.05 \\
0.12\end{array}$ & $\begin{array}{l}280 \\
255\end{array}$ & $\begin{array}{l}740 \\
142\end{array}$ \\
\hline 10 & $\begin{array}{l}\mathbf{R} \\
\mathbf{L}\end{array}$ & $\begin{array}{l}28 \cdot 33 \\
22 \cdot 0\end{array}$ & $\begin{array}{l}22 \cdot 66 \\
22 \cdot 33\end{array}$ & $\begin{array}{l}0 \cdot 16 \\
0 \cdot 09\end{array}$ & $\begin{array}{l}0.21 \\
0.14\end{array}$ & $\begin{array}{l}179 \\
244\end{array}$ & $\begin{array}{l}110 \\
161\end{array}$ \\
\hline
\end{tabular}


One eye placed on gutt. pilocarpine 2 per cent. and the other on gutt. aceclidine 2 per cent. (according to the randomized series) for a period of 2 weeks. After 2 weeks, cross-over carried out.

Trial lasted 4 weeks as for standard trial, but included only three visits, 14 days apart, at which the procedure was the same as for the standard trial.

\section{Results}

The results were evaluated statistically, using Student's $t$-test. The $t$ and $\mathrm{P}$ values are given in Table III.

Table III Statistical evaluation of results

(1) Comparison of pilocarpine and aceclidine with placebo (full trial cases only)

\begin{tabular}{|c|c|c|c|c|}
\hline Drug & $\begin{array}{l}\text { Mean intraocular } \\
\text { pressure }\end{array}$ & C-value & $P_{\mathrm{o}} / C$ & Pupil diameter \\
\hline Pilocarpine & $\begin{array}{l}\text { Per cent. fall } 25.54 \\
t=6.8 \\
P<0.001\end{array}$ & $\begin{array}{l}\text { Per cent. rise } 34.37 \\
t=4.3 \\
P<0 \cdot 001\end{array}$ & $\begin{array}{l}\text { Per cent. fall } 54 \cdot 13 \\
t=4 \cdot 8 \\
P<0 \cdot 001\end{array}$ & $\begin{array}{l}\text { Per cent. reduction } 47 \cdot 8 \\
t=14 \cdot 2 \\
P \ll 0 \cdot 001\end{array}$ \\
\hline Aceclidine & $\begin{array}{l}\text { Per cent. fall } 19.10 \\
t=5.0 \\
P<0.001\end{array}$ & $\begin{array}{l}\text { Per cent. rise } 31 \cdot 25 \\
t=4.6 \\
P<0.001\end{array}$ & $\begin{array}{l}\text { Per cent. fall } 41 \cdot 16 \\
t=3.6 \\
P<0.001\end{array}$ & $\begin{array}{l}\text { Per cent. reduction } 52 \cdot 43 \\
t=12 \cdot 7 \\
P \ll 0.001\end{array}$ \\
\hline
\end{tabular}

(2) Comparison of pilocarpine with aceclidine

\begin{tabular}{|c|c|c|c|c|c|c|}
\hline \multicolumn{2}{|l|}{ Drug } & \multirow{2}{*}{$\begin{array}{l}\text { Pilocarpine } \\
20 \cdot 28 \\
19 \cdot 05\end{array}$} & \multirow{2}{*}{$\begin{array}{l}\text { Aceclidine } \\
21 \cdot 81 \\
20 \cdot 40\end{array}$} & \multirow{2}{*}{$\begin{array}{l}\text { Difference } \\
\mathbf{I} \cdot 53 \\
\mathrm{I} \cdot 35\end{array}$} & \multirow{2}{*}{$\begin{array}{l}t \\
\begin{array}{l}3 \cdot 49 \\
2 \cdot 33\end{array}\end{array}$} & \multirow{2}{*}{$\begin{array}{l}P \\
>0.05 \\
>0.05\end{array}$} \\
\hline $\begin{array}{l}\text { Mean I.O.P. } \\
(\mathrm{mm} . \mathrm{Hg})\end{array}$ & $\begin{array}{l}\text { All cases } \\
\text { Full trial }\end{array}$ & & & & & \\
\hline Mean C-value & $\begin{array}{l}\text { All cases } \\
\text { Full trial }\end{array}$ & $\begin{array}{l}0.20 \\
0 \cdot 215\end{array}$ & $\begin{array}{l}0 \cdot 19 \\
0 \cdot 21\end{array}$ & $\begin{array}{l}0 \cdot 01 \\
0 \cdot 005\end{array}$ & $\begin{array}{l}1 \cdot 09 \\
0 \cdot 78\end{array}$ & $\begin{array}{l}>0.15 \\
>0.15\end{array}$ \\
\hline Mean $P_{o} / \mathbf{C}$ & $\begin{array}{l}\text { All cases } \\
\text { Full trial }\end{array}$ & $\begin{array}{l}110.54 \\
102 \cdot 0\end{array}$ & $\begin{array}{l}147 \cdot 65 \\
123 \cdot 38\end{array}$ & $\begin{array}{l}37 \cdot 11 \\
21 \cdot 38\end{array}$ & $\begin{array}{l}I \cdot 67 \\
I \cdot 79\end{array}$ & $\begin{array}{l}>0.15 \\
>0.15\end{array}$ \\
\hline $\begin{array}{l}\text { Pupil diameter } \\
\text { (mm.) }\end{array}$ & Full trial & I $\cdot 94$ & $\mathrm{I} \cdot 82$ & $0 \cdot 12$ & $I \cdot 24$ & $>0.15$ \\
\hline
\end{tabular}

\section{(I) INTRAOGULAR PRESSURE}

The mean intraocular pressure in cases on placebo was $25.18 \mathrm{~mm}$. $\mathrm{Hg}$. That in all cases on pilocarpine was $20 \cdot 28 \mathrm{~mm}$. $\mathrm{Hg}$ (S.E. $0 \cdot 5^{8}$ ). That for the 34 eyes on the full trial was $19.05 \mathrm{~mm}$. $\mathrm{Hg}$, and for the 20 eyes on the non-placebo trial $22.37 \mathrm{~mm}$. Hg. The mean pressure for all cases on aceclidine was $2 \mathrm{I} \cdot 8 \mathrm{I} \mathrm{mm}$. $\mathrm{Hg}$ (S.E. $0 \cdot 7 \mathrm{I}$ ), for all cases on the full trial $20.40 \mathrm{~mm}$. $\mathrm{Hg}$, and for those on the non-placebo trial $24 \cdot 19 \mathrm{~mm}$. $\mathrm{Hg}$. The percentage fall in pressure from placebo to pilocarpine was 24.5 per cent. and from placebo to aceclidine $19 \cdot 10$ per cent. Both drugs produced a statistically significant fall as compared to the placebo. The difference between the two was not significant. 
(2) AQUEOUS OUTFLOW

(a) Outflow coefficient

Mean coefficient value (G-value) on placebo o.16 (S.E. o.013).

Cases on pilocarpine $0 \cdot 20$ (S.E. $0 \cdot 013$ ) (full cases $0 \cdot 215$; non-placebo cases $0 \cdot 16$ ).

Cases on aceclidine $0 \cdot 19$ (S.E. 0.0I3) (full cases $0 \cdot 2$ I; non-placebo cases $0 \cdot 15$ ).

Percentage rise from placebo to pilocarpine 34.37 per cent., that from placebo to aceclidine $3 \mathrm{I} \cdot 25$ per cent. Both drugs produced a statistically significant increase in the coefficient-value as compared to the placebo. The difference between the two drugs was not significant.

\section{(b) Outflow fraction}

Mean $\mathrm{P}_{\mathrm{o}} / \mathrm{G}$ value for cases on placebo $209 \cdot 83$.

Cases on pilocarpine $110 \cdot 54$ (S.E. 7.56) (full cases $102 \cdot 0$; non-placebo cases $170 \cdot 5$ ).

Cases on aceclidine $147 \cdot 65$ (S.E. I I $\cdot 22$ ) (full cases $123 \cdot 38$; non-placebo cases $188 \cdot 90$ ).

Percentage change from placebo to pilocarpine $54^{\cdot} \mathrm{I} 3$ per cent., that from placebo to

aceclidine $4 \mathrm{I} \cdot \mathrm{I} 6$ per cent. Both drugs produced a statistically significant fall in the outflow fraction compared to the placebo. The difference between the two drugs was probably not significant. There was a rather large scatter in the figures.

\section{(3) PUPIL DiAMETER}

Mean diameter for cases on placebo $3 \cdot 84 \mathrm{~mm}$.

Cases on pilocarpine: overall mean $1 \cdot 87 \mathrm{~mm}$. (S.E. 0.09) (full cases $1 \cdot 94 \mathrm{~mm}$; nonplacebo cases $\mathrm{I} \cdot 7 \mathrm{I} \mathrm{mm}$.).

Cases on aceclidine: overall mean I.7I mm. (S.E. $0 \cdot 09$ ) (full cases $1 \cdot 82 \mathrm{~mm}$; nonplacebo cases $\mathrm{I} \cdot 58 \mathrm{~mm}$.).

Percentage reduction in pupil diameter from placebo to pilocarpine $47 \cdot 84$ per cent.; that from placebo to aceclidine $52 \cdot 43$ per cent. Both drugs produced significant miosis but the difference between the two was not significant.

\section{(4) HYPERAEMIA}

This was observed in 34 cases. It was more frequent with aceclidine than with pilocarpine.

\section{Discussion}

\section{(I) INTRAOGULAR PRESSURE}

In the present study, aceclidine was found to have a definite effect in lowering the intraocular pressure of eyes with open-angle glaucoma. This is in agreement with all the published work. The overall mean pressure in cases on aceclidine was $1 \cdot 53 \mathrm{~mm}$. $\mathrm{Hg}$ higher than that in cases on pilocarpine 2 per cent., a difference that is not statistically significant. The difference between the mean pressure produced by the two drugs was higher in the non-placebo cases $(1 \cdot 72 \mathrm{~mm}$.) than in the full trial cases $(1 \cdot 36 \mathrm{~mm}$.), suggesting that in patients with a high initial intraocular pressure (or a shallow anterior chamber) a stronger concentration of aceclidine might be necessary.

These results are similar to the results of the chronic experiments of Demailly (1968), in which the pressure in cases on pilocarpine was $19.1 \mathrm{~mm} . \mathrm{Hg}$, and that in cases on aceclidine 
was $20.2 \mathrm{~mm}$. Hg. However, in his acute experiments, pilocarpine produced a percentage fall in pressure of 27 ( \pm 12) compared to 30.6 ( \pm 1 3.8$)$ for aceclidine. Leopold (I968) found, in acute experiments in cases of chronic simple glaucoma, that 2 per cent. aceclidine salicylate had a greater action in lowering the intraocular pressure than pilocarpine 2 per cent. Étienne, Barut, and Gonzalès-Bouchon ( 1967 ), in twenty cases of chronic simple glaucoma, found a mean lowering of the intraocular pressure with aceclidine of $7 \cdot 65 \mathrm{~mm}$. Hg. Agugini and Stec.chi (1968) reported no difference in the hypotensive action of the two drugs when the three daily readings over 3 days were averaged, although the figure for aceclidine $(20 \cdot 95 \mathrm{~mm}$. $\mathrm{Hg})$ was slightly lower than that for pilocarpine $(22 \cdot 29 \mathrm{~mm}$. $\mathrm{Hg})$. Brancato and Boschi (1968), comparing the action of the two drugs in ten subjects, found that aceclidine was "incomparably better", but gave no statistical evaluation.

\section{AQUEOUS OUTFLOW}

It was this aspect of the effect of direct-acting parasympathomimetic miotics that appeared to be the most intriguing. In the present study, aceclidine was found to have a definite effect in improving the facility of outflow in eyes with open-angle glaucoma. The difference in the mean C-value of cases on pilocarpine and aceclidine was $0 \cdot 01$ (full trial trial cases difference $=0$; non-placebo cases difference $=0 \cdot 0 \mathrm{I}$ ). Lieberman and Leopold stated categorically that, so far as their work was concerned, aceclidine had no effect whatsoever on outflow facility (except in their chronic simple glaucoma suspects and secondary glaucoma cases), a unique property in a miotic. They observed a definite pressure-lowering effect, which led them to a most interesting theoretical discussion of how the drug produced this effect (see below). Demailly (1968), in his chronic and acute experiments, found that aceclidine produced a significant improvement in outflow but was no significant difference between the effects of pilocarpine 2 per cent. and aceclidine $\mathrm{HCl}$ 2 per cent. on the $\mathrm{C}$-value or on $\mathrm{P}_{\mathrm{o}} / \mathrm{C}$. However, the effect of aceclidine was consistently less powerful. A study, in the acute experiments, of the logarithm of the G-values, usually of a Gaussian distribution in normal subjects, revealed a significantly greater improvement with pilocarpine than with aceclidine. Among the other studies, Etienne and others (1967) found a highly significant improvement of outflow with aceclidine in cases of glaucoma simplex; the mean improvement in the $\mathrm{C}$-value was 0.048 . Riegel and Leydhecker (1967) observed an improvement in the G-value with aceclidine from a base line of 0.17 to 0.20 , rather less than the 0.22 obtained with 2 per cent. pilocarpine. Gil del Rio ( 1968 ) found a mean increase of $0.05 \mathrm{I}$. Lepri and Tota (1967) observed an improvement in C-value of the order of $0 \cdot 03$. Brancato and Boschi (I968) observed an "identical" improvement in the G-value on both drugs. Magouritsas and Coliopoulos (in press) and Mazzilli and Mazza ( 1967 ) also observed a definite improvement in outflow.

Of all the published studies, therefore, only that of Lieberman and Leopold (1967) reports no improvement in outflow with aceclidine.

\section{Mechanism of the effect of the two drugs}

(a) It could conceivably be produced by a reduction of aqueous formation. Pilocarpine itself has been demonstrated to have an inhibitory effect on the ciliary process in vitro (Berggren, 1965). This effect has not been studied for aceclidine.

(b) Demailly, comparing the effect of the two drugs, explained the greater tensionlowering effect of aceclidine by the smaller amount of reactive hypersecretion which occurs 
after the use of both drugs. That this effect was indeed greater with pilocarpine was suggested by flow-studies, using both the results of tonography, with Goldmann's $\mathrm{F}=$ $\left(P_{0}-P_{v}\right)$ formula, and suction cup studies.

(c) Bárány (1962), experimenting on the monkey Cercopithecus ethiops, demonstrated that the increase in outflow facility produced by pilocarpine could be reversed by atropine in two stages, a fast and a slow. The fast stage lasted approximately as long as the accommodative spasm produced by pilocarpine, and could correspond to a facilitation of outflow produced by a pull of the ciliary muscle on the trabecular meshwork (and possibly on the endothelial cells of Schlemm's canal). The slow phase could correspond to the abolition of a histamine-like action of pilocarpine directly on the endothelial cells or a widening of the transendothelial channels (this latter phenomenon could not be confirmed in later experiments). In some individuals an increase in facility may be mainly due to the ciliary muscle pull, whereas in others it may predominantly correspond to the effect on the endothelium. It is possible that aceclidine lacks the latter effect (it produces intense miosis, so it is probably unlikely to be without effect on the ciliary muscle).

(d) Another explanation could be related to the recent concept of the uveo-scleral flow of aqueous along the interfascicular spaces of the ciliary body directly to the venous circulation (Bill and Bárány, 1966). Pilocarpine, possibly by causing ciliary spasm, is thought $\frac{}{\omega}$ to close up this alternative pathway for aqueous outflow. The effect of aceclidine has not been studied and it could be weaker than that of pilocarpine.

\section{(3) Mrosis}

In the present study, aceclidine was found to produce slightly more powerful miosis than pilocarpine.

Demailly (1968) obtained the impression that the miosis produced after one hour was greater with aceclidine than with pilocarpine, though the pupillary diameters were not measured. Gil del Rio (1968), using an electronic flash photographic method, noted early miosis with aceclidine, starting 4 minutes after instillation and reaching its maximum between 20 and 80 minutes. Etienne and others (1967) also noted "intense miosis". Rouher ( 1966 ) observed miosis after 30 minutes, maximal after 90 minutes, the pupil then being 47 per cent. of its original diameter. Riegal and Leydhecker ( 1967 ) noted a mean pupillary diameter on pilocarpine of $\mathrm{r} \cdot 6 \mathrm{~mm}$. and on aceclidine of $\mathrm{r} \cdot 7 \mathrm{~mm}$. This would appear to be the only study in which the miotic effect of pilocarpine was noted to be 0 stronger than that of aceclidine.

\section{(4) HYPERAEMIA}

This was more frequent with aceclidine in the present study (Table IV, opposite). N Demailly (1968) observed that it produced the same degree of congestion as pilocarpine. 0 Riegel and Leydhecker ( 1967 ) observed only three cases of hyperaemia in $5^{\mathrm{I}}$ eyes, lasting only for I or 2 days.

\section{(5) BROWAGHE OR HEADAGHE}

This was noted in 23 cases (Table IV), and was more frequent with aceclidine. Itin and Ricci ( 1967 ) reported slight headache in four out of fifteen patients. 
(6) SMARTING

This occurred in thirty cases, being approximately equal with the two drugs. It also occurred in four eyes on placebo drops (Table IV).

Table IV

\begin{tabular}{|c|c|c|c|c|c|}
\hline Symptoms & Absent & $A>P$ & $P>A$ & Equal & $\begin{array}{l}\text { More with } \\
\text { placebo }\end{array}$ \\
\hline Pain, browache & ${ }_{11 * *}>31$ & ${ }_{5}^{7}>12$ & ${ }_{2}^{4}>6$ & ${ }_{2}^{3}>5$ & - \\
\hline Smarting & ${ }_{5}^{19}>24$ & ${ }_{2}^{10}>12$ & ${ }_{9}^{2}>$ II & $6^{1}>7$ & ${ }_{0}^{4}>4$ \\
\hline Hyperaemia & ${ }_{7}^{13}>20$ & ${ }_{8}^{10}>18$ & $0^{2}>2$ & ${ }_{5}^{9}>14$ & $0^{2}>2$ \\
\hline Watering & ${ }_{9}^{24}>33$ & ${ }_{4}^{3}>7$ & ${ }_{2}^{2}>4$ & ${ }_{5}^{5}>10$ & - \\
\hline Rhinorrhoea & ${ }_{8}^{15}>12$ & ${ }_{4}^{8}>12$ & ${ }_{1}^{3}>4$ & ${ }_{7}^{8}>15$ & - \\
\hline Sialorrhoea & ${ }_{19}^{30}>49$ & 0 & ${ }_{0}^{1}>1$ & ${ }_{1}^{3}>4$ & +1 \\
\hline
\end{tabular}

* refers to cases in the full trial

** refers to cases in the non-placebo trial

\section{(7) BLURRING AND DARKENING OF VISION}

These occurred in 38 and 28 cases respectively, being more frequently noted with aceclidine. In Demailly's experience accommodative myopia is the same as with pilocarpine. The only other reference in the published work to this symptom is that of Itin and Ricci (1967), who noted transient visual disturbances in four out of fifteen patients.

(8) SIALORRHOEA

This occurred in seven cases and was rather more frequent with pilocarpine than with aceclidine (Table IV). This is in contrast with the observations of Etienne and others ( 1967 ), who found that aceclidine produced no sialorrhoea in man as it did in animals.

\section{（9） RHINORRHOEA}

This occurred in $3^{1}$ cases, more often with aceclidine than with pilocarpine (Table IV).

(I0) SNEEZING

This occurred in eight cases: in four with aceclidine, one with pilocarpine, and three equally with both drugs. It also occurred in one case on placebo drops. The literature here is conflicting: Demailly (1968) reported no instance of sneezing following the instillation of aceclidine, whereas Étienne and others ( 1967$)$ reported it in all patients. 
None was observed, and this finding is similar to that of other workers. Such disturbances are, in fact, seldom observed with pilocarpine but are frequent with carbachol, together with other manifestations of systemic intoxication.

\section{Long-term tolerance of aceclidine}

The following brief histories of patients outside the double-blind series are included as examples of good acceptance of aceclidine when pilocarpine was not tolerated.

(I) Mrs. E. W.

Irritation on pilocarpine with intolerable discomfort. Given aceclidine for 6 months. Quite comfortable on this therapy. Seen at 3-weekly intervals: ocular tension between 12 and $20 \mathrm{~mm}$. $\mathrm{Hg}$.

(2) Mrs. W. P.

Much irritation on pilocarpine. Given aceclidine for 19 months. Much less irritation, though more "darkening". Pressure during entire period between 20 and $22 \mathrm{~mm}$. $\mathrm{Hg}$ (had been $32 \mathrm{~mm}$. previously). On resuming pilocarpine the pressures were around $24 \mathrm{~mm}$. $\mathrm{Hg}$ in each eye. Complained of pain around eyes and discharge. Eppy and eventually hydrocortisone drops necessary.

(3) Mrs. D. B.

Irritation on pilocarpine. Given aceclidine for 3 months. Initial comfort but slight discomfort for one month which passed off. Tension 23 to $27 \mathrm{~mm}$. $\mathrm{Hg}$ on pilocarpine 2 per cent., and $2 \mathrm{I}$ to $24 \mathrm{~mm}$. Hg on aceclidine. Resumed pilocarpine 3 per cent. and eserine 0.5 per cent. Gradually developed intense hyperaemia and discomfort. Local steroids attempted. Tosmilen eventually tried.

(4) Mrs. T. P.

Allergic to pilocarpine. Was receiving gutt. Betnesol. Given aceclidine for 12 months with excellent tolerance, nuch less discomfort, and much less congestion. With Eppy I per cent. in addition control was satisfactory. (Tensions $2 \mathrm{I}$ to $22 \mathrm{~mm}$. $\mathrm{Hg}$ at all times.) When pilocarpine 2 per cent. was resumed the tensions were around 24 to $26 \mathrm{~mm}$. $\mathrm{Hg}$ and she again complained of discomfort.

(5) Mr. T.S.

Sensitive to pilocarpine and eserine, and was given phospholine iodide with Eppy. The tensions were 24 to $26 \mathrm{~mm}$. Hg. Given aceclidine with Eppy and seen monthly for a year. Much more comfortable. Pressures around $\mathrm{I} 7$ to $24 \mathrm{~mm}$. Hg. When pilocarpine 3 per cent. was resumed absolute intolerance was complained of. Again given aceclidine and discomfort disappeared. When supplies of aceclidine were exhausted prostigmine (neostigmine) 3 per cent. was tried but caused a considerable burning sensation which was soothed to some extent by adrenaline.

\section{Summary}

The results of a double-blind cross-over comparison of aceclidine hydrochloride 2 per cent. and pilocarpine 2 per cent. in 54 glaucomatous eyes are presented. Both eye drops produced a significant lowering of intraocular pressure and improvement in outflow and in the degree of miosis, but the differences between the two were small and not significant. Hyperaemia and a variety of subjective symptoms were also compared: neither drug produced serious side-effects or discomfort. Aceclidine would appear to deserve a place 
beside pilocarpine as a stable direct parasympathomimetic drug in the treatment of openangle glaucoma, especially if pilocarpine is not tolerated, or if it is ineffective, or becomes so after a period of use.

My thanks are due to Messrs. Chibret, France, for generous supplies of aceclidine and assistance with the Continental literature, to Mr. Redmond J. H. Smith for his advice and encouragement, and to Mr. Baker, Chief Pharmacist, Moorfields Eye Hospital, for organizing the dispensing of random series of eye drops.

\section{References}

AGUGini, c., and STECGHI, G. (1968) Ann. Ottal., 94, I

BÁRÁNY, E. H. (1962) Invest. Ophthal., r, 712

BERGGREN, L. (1965) Ibid., 4, 91

BILl, A., and BÁRANY, E. H. (1966) Arch. Ophthal. (Chicago), 75, $66_{5}$

BRANCATO, R., and BOSGH, M. G. (1968) Ann. Ottal., 94, 1077

DEMAILly, P. (1968) Arch. Ophtal., 28, 735

Étienne, R., barut, C., and gonzalès-bouchon, J. (1967) Ann. Oculist. (Paris), 200, 287

GIL DEL RIO, E. (1968) Arch. Soc. oftal. hisp.-amer., 28, 396

ITIN, W., and RICCI, A. (1967) Report of Ophthalmological Clinic of the University of Geneva.

Dir. Prof. J. Babel

LEOPOLD, I. H. (1968) Amer. F. Ophthal., 65, 297

LEPRI, G., and TOTA, G. (1967) Ann. Ottal., 93, 634

LIEBERMAN, T. W., and LeOPOLD, I. H. (1967) Amer. J. Ophthal., 64, 405

MAGOURITSAS, N., and coliopoulos, J. (in press) L'acéclidine dans le traitement du glaucome MashKovsKi, M. D., and Zartzeva, K. (1960) Farmakol. Toxicol., 23, 398

MAZzA, c., and MAZzilli, G. (1967) Ann. Ottal., 93, 1430

MAZZILLI, G., and MAZZA, c. (1967) Ibid., 93, 745

RIEGEL, D., and Leydhecker, w. (1967) Klin. Mbl. Augenheilk., 151, 882

RouHer, F. (1966) Revue Chibret, No. 47

RUBitzov, M. v., and miklina, E. (1960) Cited by Mashkovski and Zaitzeva (1960)

SHAFFer, R. N. (1967) In "Symposium on Glaucoma: Transactions of the New Orleans Academy of Ophthalmology", p. 129. Mosby, St. Louis

SHARTS, s. I., and SHULPINA, H. B. (196I) Oftal. Zh., no. 6 , p. 348

sWAN, K. c. (1959) In "Symposium on Glaucoma", ed. W. B. Clark. Mosby, St. Louis TARRERIAS, H., and vasSallo, J. (1967) "Study of Stability". Chibret Laboratory Report yankelowitz, s. (1965) "Pharmacological evaluation of aceclidine". Pharmacology Lab.

Report-Smith, Miller, and Patch, Inc., N.J. Cited by Lieberman and Leopold, 1967 